\title{
Patient Reported Outcomes Instruments in Schizophrenia: A Review of Psychometric Properties
}

\author{
Aurelie Millier ${ }^{1 *}$, Emilie Clay ${ }^{1}$, Insaf Charaf ${ }^{2}$, Deven Chauhan ${ }^{3}$, Venkatesha Murthy ${ }^{3}$, \\ Mondher Toumi ${ }^{4}$, Nadia Cadi-Soussi ${ }^{5}$ \\ ${ }^{1}$ Creativ-Ceutical, Paris, France \\ ${ }^{2}$ Creativ-Ceutical, Tunis, Tunisia \\ ${ }^{3}$ Takeda Pharmaceuticals, London, UK \\ ${ }^{4}$ University Claude Bernard Lyon I, Lyon, France \\ ${ }^{5}$ Takeda Pharmaceuticals, Zurich, Switzerland \\ Email: ami@creativ-ceutical.com, ecl@creativ-ceutical.com, ich@creativ-ceutical.com, d.chauhan@tgrd.com, \\ venkatesha.murthy@takeda.com, mondher.toumi@univ-lyon1.fr, nadia.cadi-soussi@takeda.com
}

Received November 15, 2013; revised December 15, 2013; accepted December 22, 2013

Copyright (c) 2014 Aurelie Millier et al. This is an open access article distributed under the Creative Commons Attribution License, which permits unrestricted use, distribution, and reproduction in any medium, provided the original work is properly cited. In accordance of the Creative Commons Attribution License all Copyrights (C) 2014 are reserved for SCIRP and the owner of the intellectual property Aurelie Millier et al. All Copyright (C) 2014 are guarded by law and by SCIRP as a guardian.

\section{ABSTRACT}

Background: Interest in the self-perception of patients with mental illness is increasing because of the gap between the physician and patient perceptions of symptoms and drug side effects. Schizophrenia is one of the mental illnesses that cause the greatest difficulty in understanding the various physical and psychological impacts related to both symptoms and drug treatment. Thus, several patient-reported outcomes (PRO) have been developed to get a clearer understanding of patients' experience with their own illness and the treatment that they receive. Objective: The aim of this study was to identify all PRO questionnaires used in the evaluation of patients with schizophrenia, and to assess the quality of these questionnaires based on psychometric evidence. Methods: All PRO questionnaires used in the evaluation of patients with schizophrenia were identified using a search strategy in Pubmed, Medline, and the ISPOR website. PRO psychometric properties were extracted, and their level of validation was assessed. Results: The literature search resulted in the identification of 70 generic, mental health-specific or schizophrenia-specific instruments. These questionnaires were categorized according to measured domains. Six major domains were identified: health related quality of life (HRQoL), insight, depression/ feelings, treatment related, illness symptoms, and caregiver/family. Questionnaires measuring other dimensions were classified as other (related to personality measurement, communication between patients and clinicians and services satisfaction). The review shows that the HRQoL questionnaires demonstrate the best psychometric properties. Conclusion: The assessments of these questionnaires, based on their psychometric evidence level, will allow researchers to choose the most appropriate PRO instruments, based on the instruments' ability to respond to the objectives of the study and on the rigor of their psychometric qualities. As schizophrenia is a multidimensional mental illness, we argue that a single PRO questionnaire is insufficient to obtain a clear understanding of the condition and treatment effects in patients with schizophrenia. Thus, we think that new PRO instruments in schizophrenia should be developed.

\section{KEYWORDS}

Schizophrenia; PRO; Validation; Psychometric Properties

\section{Introduction}

Schizophrenia is a chronic, severe, and disabling brain disorder [1]. Worldwide, approximately seven per thou-

\footnotetext{
"Corresponding author.
}

sand adults (15 - 35 years old) develop schizophrenia during their lifetime [2]. The severity of the symptoms and long-lasting, chronic pattern of schizophrenia often cause a high degree of disability.

Three large concepts define the schizophrenia's symp- 
tomatology: positive symptoms, negative symptoms, and cognitive symptoms [3]. Positive symptoms include hallucinations, delusions and thought disorders. Negative symptoms are symptoms associated with disruptions to normal emotions and behaviors, such as lack of pleasure in everyday life or lack of ability to begin and sustain planned activities. Cognitive symptoms include poor executive functioning, trouble focusing or paying attention, and problems with working memory, and can cause great emotional distress.

Many hypotheses were generated in order to understand the causes of schizophrenia, but no single approach was sufficient. Thus, the development of treatment primarily aimed at elimination of symptoms [3]. Treatments include antipsychotic medications and various psychosocial therapies. Compliance with therapy allows the reduction and control of symptoms. However, it doesn't totally suppress them, and some residual symptoms have to be endured by patients with schizophrenia for a lifetime [3].

Multiple questionnaires exist to assess treatment benefit for patients with schizophrenia [4]. In a context where physicians and payers consider not only evidence-based information, but also patient-oriented criteria, it is necessary to distinguish between questionnaires answered by physicians also called clinician-reported outcomes (ClinROs), patient reported outcomes (PROs) and observer-reported/caregiver-reported outcomes (ObsROs), to capture a complete understanding of this patient population. According to the US Food and Drug Administration (FDA) definition (2010) [5], PROs are what patients report directly about their health condition, without any clinical interpretation by physicians or researchers. PROs present several advantages. First, PRO data are gathered from the information given directly by patients, without any clinical interpretation (improvement in clinical measures may not correspond to improvement from a patient's point of view) [4]. Second, some treatment effects are only perceived by patients and hence cannot be measured by physicians (e.g. pain) and are not accompanied by physical signs. Third, patient-rated outcomes engage the consumers/patients in their mental health care [4]. However, PROs in schizophrenia face a major limitation: psychiatric symptoms, such as hallucinations and delusions, may impact the patient's judgment and make it unreliable. The issue of insight may also be a hurdle. In spite of the potential difficulties in obtaining outcomes information from patients with certain types of mental illness, evidence suggests that even among those with chronic and severe mental illness, patients are able to evaluate their condition, and the information they provide is unique and invaluable [6]. A recent study has demonstrated that it is feasible to routinely collect mental health outcomes data from patients with schizophrenia in maintenance phase [7]. Although there is important on- going clinical debate regarding whether or not PROs should be used in clinical trials to assess treatment efficacy, PROs in schizophrenia are widely used. Another generic limitation of PROs is that they are considered time-consuming, and that patients regard data collection as a burden [8]. They may suffer from what is called "survey fatigue" and become reluctant to fill in questionnaires.

There exist over 3000 generic and disease-specific PRO instruments [9], and some are now widely used in research contexts. With the rising use of PROs in clinical settings or to support decision-making, researchers are now facing the issue of which instruments to choose. As such a review of the evidence concerning PROs in the complex field of schizophrenia would be beneficial. The aim of the present review is to conduct a systematic literature review to identify all PRO questionnaires used in the evaluation of patients with schizophrenia, and to evaluate the quality of these questionnaires based on their psychometric evidence directly related to samples of patients with schizophrenia.

\section{Methods}

\subsection{Search Strategy}

A computerized literature search was performed using Pubmed, Medline, and the ISPOR website (Table 1). The search was conducted by two reviewers. Additional references were selected through searching the references cited by the identified studies.

There were no language restrictions, as translations were done when required.

The two reviewers independently assessed the titles and abstracts of all collected publications for possible inclusion in the study; disagreements between reviewers were resolved by consensus.

\subsection{Selection Criteria}

Specific criteria guided the selection of articles and abstracts discussing the different PRO instruments. Based on the FDA definition of PRO, we selected only the patient-rated questionnaires. We extracted the target popu-

Table 1. Search strategy.

\begin{tabular}{lll}
\hline SOURCE & KEY WORDS & $\begin{array}{l}\text { PRESELECTED } \\
\text { REFERENCES \# }\end{array}$ \\
\hline & $\begin{array}{l}\text { \#1: “schizophrenia”/exp } \\
\text { AND [abstracts]/lim }\end{array}$ & 79,240 \\
$\begin{array}{l}\text { Embase + } \\
\text { Medline }\end{array}$ & $\begin{array}{l}\text { “patient-reported outcome” OR “pro” } \\
\text { 121,681 results }\end{array}$ & 322 results \\
& \#1 AND \#2 & \\
ISPOR & $\begin{array}{l}\text { schizophrenia + patient-reported } \\
\text { outcomes }\end{array}$ & 103 results \\
\hline
\end{tabular}


lation (generic or specific), the dimensions, languages in which they are developed or translated, and the number of items. Also, we specified whether the article retrieved was dedicated to the PRO validation (described in the abstract) or only mentioned the PRO level of validity (not described in the abstract). Finally, we extracted psychometric properties such as reliability (internal consistency and reproducibility), validity (content validity and construct validity) and sensitivity to change. Table 2 defines these parameters.

Reliability, validity and sensitivity to change were assessed by two trained analysts having at least 3 years' experience in the field. Analysts independently rated the level of reliability, validity and sensitivity to change as robust $(++)$, moderate $(+)$ or poor $(-)$. Basically, analyses were considered robust when all evidence was provided in the publication, and suggested a high quality, as moderate when only part of the evidence was provided, and poor when not all analyses were performed, or when the level of evidence suggested a low quality.

The rating was based on the number and the kind of the analyses run, and obviously on their results. For example, if only the internal consistency is assessed but no test-retest analysis is performed, the reliability could not be rated as robust, as only one aspect of reliability was tested. When no quantitative results were reported in the publication to support authors' conclusions, analysts stated "not detailed". In other cases, analysts stated "not assessed".

\section{Results}

\subsection{Overview of Studies}

A large number of PRO questionnaires have been developed for patients with schizophrenia. A total of 177 abstracts were selected (114 from Embase/Medline, 51 from ISPOR and 12 from other sources). Excluded were 107 references that did not present any PRO for patients with schizophrenia, and finally 70 references were se- lected in the present review. As outcomes in schizophrenia may be divided into several categories that are largely independent of each other, 10 domains were defined from the selected questionnaires, namely quality of life, depression/feelings, insight, treatment-related, illness symptoms, personality measure, social functioning, communication patient/clinician, services satisfaction and PRO related to caregiver and family burden. Below, we regroup PRO questionnaires according to their domains.

Although all psychometric characteristics were extracted from the 70 references, they could not be fully reported in this article. They are available on request.

\subsection{Health Related Quality of Life Questionnaire (HRQoL)}

Quality of life it is a complex multidimensional concept. It provides information about the patient's evaluation of life in its both positive and negative aspects. Several domains are included in the quality of life concept, such as job, housing, school, aspects of culture, values, spirituality, etc. Health is one of the most important dimensions of the QoL concept [10,11]. HRQoL measurement has become an important outcome both in health assessment and in judging clinical improvement $[12,13]$. Health care community argues that individual's health is a multidimensional concept including physical, mental and social domains [14]. It can also include emotional and behavioral components of well being and functioning. HRQoL represents, then, the patient's perception of his physical and mental health condition and of the functional impact of illness on them. In recent years, instruments to measure HRQoL in mental health have been progressively incorporated as a means of measuring the effects of interventions on symptoms and functioning.

Table 3 presents the 18 PRO instruments retrieved from our literature review that were used to evaluate HRQoL in schizophrenia.

The TOOL [15-18], a specific measure to assess

Table 2. Definition of psychometric properties.

\begin{tabular}{|c|c|}
\hline & Definition \\
\hline Reliability & $\begin{array}{l}\text { The reliability of a questionnaire is the stability of a measurement instrument, that is, the extent to which the } \\
\text { instrument yields the same results on repeated experiment when no change in the concept being measured has } \\
\text { occurred [57,58]. It also includes internal consistency: the method assumes that the instrument contains multiples } \\
\text { domains, each of which is scored and combined with the scores of the other domains to produce an overall score. } \\
\text { Internal consistency ensures that the items included in a domain are all evaluating the same concept. }\end{array}$ \\
\hline Validity & $\begin{array}{l}\text { The validity of a questionnaire is the extent to which it measures what it is intended to measure. Validity must be } \\
\text { determined, therefore, in relation to the purpose of the questionnaire }[58,59] \text {. Validity includes content validity and } \\
\text { construct validity. Content validity is the relationship between the content and the purpose of the questionnaire, } \\
\text { i.e., whether or not there is a good match between the test specification and the task specification [59,60]. Construct } \\
\text { validity is the extent to which a test's results measure a theoretical construct, such as ability or a personality trait [61]. }\end{array}$ \\
\hline Sensitivity to change & $\begin{array}{l}\text { This evaluative dimension has two components: the degree to which true change in a variable or functional relation } \\
\text { is captured by a measure and the latency between change in the variable and change in the measure [62,63]. }\end{array}$ \\
\hline
\end{tabular}


Table 3. HRQoL PRO instruments.

\begin{tabular}{|c|c|c|c|c|c|c|c|c|c|c|}
\hline \multicolumn{5}{|c|}{ General instrument characteristics } & \multicolumn{6}{|c|}{ Articles information } \\
\hline Name & $\begin{array}{l}\text { Complete } \\
\text { name }\end{array}$ & $\begin{array}{l}\text { Generic/ } \\
\text { specific }\end{array}$ & $\begin{array}{l}\text { Number } \\
\text { of items }\end{array}$ & Dimensions & $\begin{array}{l}\text { Type of } \\
\text { study }\end{array}$ & Language & Validity & Reliability & $\begin{array}{l}\text { Sensitivity } \\
\text { to change }\end{array}$ & Reference \\
\hline SLDS & $\begin{array}{l}\text { Satisfaction } \\
\text { with Life } \\
\text { Domains Scale }\end{array}$ & $\begin{array}{l}\text { Schizophrenia- } \\
\text { specific }\end{array}$ & 15 & $\begin{array}{l}\text { Home, neighborhood, } \\
\text { food, clothing, health, } \\
\text { cohabitants, friendships, } \\
\text { family, relationships with } \\
\text { other people, daily } \\
\text { activity, freetime, leisure, } \\
\text { services and facilities at } \\
\text { place of residence, } \\
\text { economic situation, place } \\
\text { of residence compared } \\
\text { with the hospital }\end{array}$ & Validation & Spanish & + & + & NA & Carlson [64] \\
\hline S-QoL & $\begin{array}{l}\text { Quality-of-Life } \\
\text { Questionnaire } \\
\text { in } \\
\text { Schizophrenia }\end{array}$ & $\begin{array}{l}\text { Schizophrenia- } \\
\text { specific }\end{array}$ & 41 & $\begin{array}{l}\text { Psychological well-being, } \\
\text { self-esteem, relations with } \\
\text { family, relations with } \\
\text { friends, resilience, } \\
\text { physical well-being, } \\
\text { autonomy and } \\
\text { sentimental life }\end{array}$ & Validation & $\begin{array}{l}\text { French } \\
\text { English } \\
\text { (UK) }\end{array}$ & ++ & - & + & $\begin{array}{l}\text { Lançon [65] } \\
\text { Auquier [66] }\end{array}$ \\
\hline W-QLI & $\begin{array}{l}\text { Wisconsin } \\
\text { Quality of Life } \\
\text { Index }\end{array}$ & $\begin{array}{l}\text { Severe mental } \\
\text { illness specific }\end{array}$ & 47 & $\begin{array}{l}\text { Satisfaction with life } \\
\text { domains, occupational } \\
\text { activities, symptoms, } \\
\text { physical health, social } \\
\text { relations/support, } \\
\text { finances, psychological } \\
\text { wellbeing, activities of } \\
\text { daily living }\end{array}$ & Validation & $\begin{array}{l}\text { French and } \\
\text { English } \\
\text { (Canada) }\end{array}$ & ++ & - & NA & $\begin{array}{c}\text { Caron [68] } \\
\text { Diaz [69] }\end{array}$ \\
\hline \multirow{2}{*}{ SQLS } & \multirow{2}{*}{$\begin{array}{l}\text { Schizophrenia } \\
\text { Quality of Life } \\
\text { Scale }\end{array}$} & \multirow{2}{*}{$\begin{array}{l}\text { Schizophrenia- } \\
\text { specific }\end{array}$} & \multirow{2}{*}{30} & \multirow{2}{*}{$\begin{array}{l}\text { Psychological, motivation } \\
\text { and energy, symptoms } \\
\text { side-effects }\end{array}$} & Validation & English & + & - & + & $\begin{array}{l}\text { Wilikinson } \\
\text { [70] }\end{array}$ \\
\hline & & & & & Validation & Chinese & + & ++ & ++ & Luo [72] \\
\hline SQLS-4 & $\begin{array}{l}\text { Schizophrenia } \\
\text { Quality of Life } \\
\text { Scale-Revision } \\
4\end{array}$ & Schizophrenia & 33 & Psychosocial, vitality & Validation & Chinese & + & ++ & + & Kuo [73] \\
\hline $\begin{array}{l}\text { SWN- } \\
\text { long form }\end{array}$ & $\begin{array}{l}\text { Subjective } \\
\text { Well-Being } \\
\text { under } \\
\text { Neuroleptics } \\
\text { Scale-long } \\
\text { form }\end{array}$ & $\begin{array}{l}\text { Severe mental } \\
\text { illness specific }\end{array}$ & 38 & $\begin{array}{l}\text { Emotional regulation, } \\
\text { mental functioning, self } \\
\text { control, social integration, } \\
\text { physical functioning }\end{array}$ & Validation & English & ++ & + & + & $\begin{array}{l}\text { Naber } \\
{[19,20]}\end{array}$ \\
\hline $\begin{array}{l}\text { SWN- } \\
\text { short form }\end{array}$ & $\begin{array}{l}\text { Subjective } \\
\text { Well-Being } \\
\text { under } \\
\text { Neuroleptics } \\
\text { Scale_-short } \\
\text { form }\end{array}$ & $\begin{array}{l}\text { Severe mental } \\
\text { illness specific }\end{array}$ & 20 & $\begin{array}{l}\text { Emotional regulation, } \\
\text { mental functioning, self } \\
\text { control, social integration, } \\
\text { physical functioning }\end{array}$ & Validation & English & ++ & + & NA & Lee [21] \\
\hline S.QUA.L.A & $\begin{array}{l}\text { Subjective } \\
\text { AQuality of Life } \\
\text { Analysis }\end{array}$ & NA & $\bullet$ & ND & Validation & French & - & + & NA & Nadalet [74] \\
\hline Q-LES-Q & $\begin{array}{l}\text { Quality of Life } \\
\text { Enjoyment and } \\
\text { Satisfaction } \\
\text { Questionnaire }\end{array}$ & $\begin{array}{l}\text { Mentally } \\
\text { disabled } \\
\text { patients }\end{array}$ & 60 & $\begin{array}{l}\text { Physical health, subjective } \\
\text { feelings, leisure activities, } \\
\text { social relationships, } \\
\text { general activities, } \\
\text { satisfaction with } \\
\text { medication and life } \\
\text { satisfaction }\end{array}$ & Validation & Finnish & + & - & NA & $\begin{array}{l}\text { Pitkänen } \\
\text { [75] }\end{array}$ \\
\hline
\end{tabular}




\section{Continued}

Quality of Life

Q-LES-Q- Enjoyment and

18 Satisfaction NA

Questionnaire

EQ-5D EuroQol-5D Generic

The Health

HUI3 Utilities Index Generic

Mark 3

The

Tolerability

TOOL and Quality of Severe mental

Life

Questionnaire

The

Schizophrenia SchizophreniaQuality of Life specific

Scale

The Quality of

Life Measure

QOLM-S for Persons Schizophrenia with

Schizophrenia

51-item

Schizophrenia

SOAP-51 Outcomes Schizophrenia

Assessment

Project

AQoL $\begin{aligned} & \text { Assessment of } \\ & \text { Quality of Life }\end{aligned}$

SF-36 $\begin{aligned} & \text { Short Form } 36 \\ & \text { Health Survey }\end{aligned}$ Generic

Validation

Hebrew,

Arabic

(Israël)

English

Dannish,

Franch,

German,

Mobility, self-care, usual

5 activities, pain/disconfort, Validation

Greeck,

Irish,

Italian,

Dutch,

Portugese,

Spanish

Vision, hearing, speech,

8 ambulation, dexterity,

emotion, cognition, pain

Validation Singapore ++

NA

NA

Luo [79]

Mood, function

capabilities,

fatigue-weakness, weight

8 gain, stiffness-tremor,

physical restlessness,

sexual dysfunction,

dizzyness nausea

Professional life, affective

and sexual life, illness

knowledge, relationship,

life satisfaction, coping

74 with drugs, drugs impac on the body, daily life,

Validation French ++ ++

family relationship, future,

security feeling, leisure,

money management and

autonomy

NA

$++$

$++$

NA

Laliberte-

Rudman

[81]

Satisfaction, self concept, work/role, mental health,

51 interpersonal, medication

effects, activities of daily

Validation

English

ND

ND

NA

Barr

living, and physical

function

$15 \mathrm{ND}$

Validation NA

$$
\text { ND }
$$

NA

Adams

$[85,86]$

Vitality, physical

functioning, bodily pain, general health perceptions,

physical role, fu emotional role

Ruppert

functioning, social role

functioning, mental health

++: Robust; +: Moderate; -: Poor; NA: Not Assessed; ND: Not Detailed.

HRQoL impairment related to adverse events of antipsychotic drugs using a 8-item specific scale, demonstrated the strongest psychometric properties. The SWN questionnaire [19-21], like the TOOL, shows a high validity. However, reliability and sensitivity to change are less validated than those of the TOOL. The Schizophre- 
nia Quality of Life Scale Revision 4 (SQLS-4) is the result of the several revisions made to the SQLS to improve its psychometric properties. The SQLS-R4 contains 33 items in two domains: psychosocial (20 items) and vitality (13 items). The Q-LES-Q-18 is a core subset of the Quality of Life Enjoyment and Satisfaction Questionnaire (Q-LES-Q) items that maintains the validity and psychometric properties of the basic version. It has the advantage of a 10-12 min administration time, compared to the basic Q-LES-Q, which took 40 - 45 min to complete. The EQ-5D and the SF-36 are widely used, and allow calculation of patient utility.

\subsection{Insight PRO Instruments}

Definition of insight has much evolved since recent decades: from a "patient's awareness about a mental disorder that is either present or absent” [22-24] to "patient's awareness that he or she is suffering from a mental illness, experiencing symptoms of that illness, in need of treatment, and that the cause of symptoms is the illness" [25,26].

Despite "insight” being primarily a clinician's concept, there exist several self-rated instruments.

Four Insight PRO instruments were selected in this present study (Table 4). With no assessed sensitivity to change, the ABPS [27] shows high validity and reliability. The BCIS [28] has a high validity but reliability and sensitivity to change were not assessed.

\subsection{Emotional Well Being}

Learning how depression, stress and anxiety may affect patients with schizophrenia is one of the major concerns of clinicians nowadays. Depression is a frequently occurring symptom in schizophrenia. It is often under-recognised and under-treated. Few PRO instruments aim to measure symptoms of depression, or other feelings like anger.

Table 5 presents five depression/feeling PRO instruments, but no one has the psychometric properties required. Indeed, in the majority of these PRO instruments, neither the validity nor the reliability was assessed in the population of patients with schizophrenia.

\subsection{Treatment-Related PRO Instruments}

Neuroleptic medication is the most widely used treatment for schizophrenia. It is effective in reducing psychotic symptoms, but compliance is often poor because neuroleptic drugs are associated with a wide range of side-effects. Medication-related PRO instruments can measure different variables related to treatment: the response to the medication, the adherence or compliance to the treatment, or the side-effects.

Eleven treatment-related PRO instruments were selected (Table 6). In all of these PRO instruments, the sensitivity to change was not assessed. The LUNSERS [29], a 51-item specific scale, shows high validity and reliability.

Table 4. Insight PRO instruments.

\begin{tabular}{|c|c|c|c|c|c|c|c|c|c|c|}
\hline \multicolumn{5}{|c|}{ General instrument characteristics } & \multicolumn{6}{|c|}{ Articles information } \\
\hline Name & Complete name & Generic/Specific & $\begin{array}{l}\text { Number } \\
\text { of items }\end{array}$ & Dimensions & $\begin{array}{l}\text { Type of } \\
\text { study }\end{array}$ & Language & Validity & Reliability & $\begin{array}{l}\text { Sensitivity } \\
\text { to change }\end{array}$ & Reference \\
\hline IS & $\begin{array}{l}\text { The Birchwood } \\
\text { Insight Scale }\end{array}$ & $\begin{array}{l}\text { Mental } \\
\text { illness-specific }\end{array}$ & 8 & $\begin{array}{l}\text { Awareness, relabel, } \\
\text { need of treatment }\end{array}$ & $\begin{array}{l}\text { Validation } \\
\text { Validation }\end{array}$ & $\begin{array}{l}\text { English } \\
\text { (USA) } \\
\text { Italian }\end{array}$ & + & ++ & NA & $\begin{array}{l}\text { Pedrelli } \\
\text { [88] } \\
\text { Roncone } \\
\text { [89] }\end{array}$ \\
\hline SAIQ & $\begin{array}{l}\text { The } \\
\text { Self-Appraisal } \\
\text { of Illness } \\
\text { Questionnaire }\end{array}$ & $\begin{array}{l}\text { Mental } \\
\text { illness-specific }\end{array}$ & 17 & $\begin{array}{l}\text { Awareness of the illness, } \\
\text { believes about illness } \\
\text { consequences, awareness } \\
\text { of the need of psychiatric } \\
\text { treatment, importance } \\
\text { worries about the illness }\end{array}$ & Mentioned & French & - & NA & NA & $\begin{array}{c}\text { Travers } \\
\text { [90] }\end{array}$ \\
\hline BCIS & $\begin{array}{l}\text { The Beck } \\
\text { Cognitive } \\
\text { Insight Scale }\end{array}$ & $\begin{array}{l}\text { Psychotic } \\
\text { disorder-specific }\end{array}$ & 15 & $\begin{array}{l}\text { Self-reflectiveness, } \\
\text { self-certainty }\end{array}$ & Validation & $\begin{array}{l}\text { English } \\
\text { (USA) }\end{array}$ & ++ & NA & NA & Beck [28] \\
\hline ABPS & $\begin{array}{l}\text { The Awareness } \\
\text { of Being a } \\
\text { Patient Scale }\end{array}$ & Schizophrenia & 25 & $\begin{array}{l}\text { Recognition of the need } \\
\text { for treatment in general, } \\
\text { for neuroleptic medication } \\
\text { and for participation in } \\
\text { treatment and attitude } \\
\text { toward psychiatric } \\
\text { treatment, medication, } \\
\text { treatment staff and peer } \\
\text { patients }\end{array}$ & Validation & Japanese & ++ & ++ & NA & $\begin{array}{l}\text { Hayashi } \\
\text { [27] }\end{array}$ \\
\hline
\end{tabular}

++: Robust; +: Moderate; -: Poor; NA: Not Assessed; ND: Not Detailed. 
Table 5. Emotional well-being PRO instruments.

\begin{tabular}{|c|c|c|c|c|c|c|c|c|c|c|}
\hline \multicolumn{5}{|c|}{ General instrument characteristics } & \multicolumn{6}{|c|}{ Articles information } \\
\hline Name & Complete name & $\begin{array}{l}\text { Generic/ } \\
\text { Specific }\end{array}$ & $\begin{array}{l}\text { Number } \\
\text { of items }\end{array}$ & Dimensions & $\begin{array}{l}\text { Type of } \\
\text { study }\end{array}$ & Language & Validity & Reliability & $\begin{array}{l}\text { Sensitivity } \\
\text { to change }\end{array}$ & Reference \\
\hline BDI & $\begin{array}{l}\text { The Beck } \\
\text { Depression } \\
\text { Inventory }\end{array}$ & Generic & 21 & $\begin{array}{l}\text { Depression } \\
\text { (unidimensional scale) }\end{array}$ & Mentioned & $\begin{array}{l}\text { English } \\
\text { (USA) }\end{array}$ & NA & + & NA & Bell [91] \\
\hline PD-S & $\begin{array}{l}\text { Paranoid-Depressivity } \\
\text { Scale }\end{array}$ & NA & ND & ND & Validation & NA & NA & NA & NA & $\begin{array}{c}\text { Schaeffer } \\
\text { [92] }\end{array}$ \\
\hline FBS & $\begin{array}{l}\text { Frankfurt Self-feeling } \\
\text { Scale (Frankfurter } \\
\text { Befindlichkeitsskala) }\end{array}$ & NA & ND & ND & Validation & NA & NA & NA & NA & $\begin{array}{c}\text { Schaeffer } \\
\text { [92] }\end{array}$ \\
\hline SAEI-28 & $\begin{array}{l}\text { Suicide Anger } \\
\text { Expression } \\
\text { Inventory-28 }\end{array}$ & NA & 28 & $\begin{array}{l}\text { Suicide rumination, } \\
\text { maladaptive } \\
\text { expression, reactive } \\
\text { distress, and adaptive } \\
\text { expression }\end{array}$ & Validation & $\begin{array}{l}\text { English } \\
\text { (USA) }\end{array}$ & ++ & NA & NA & $\begin{array}{l}\text { Osman } \\
\text { [93] }\end{array}$ \\
\hline
\end{tabular}

++: Robust; +: Moderate; -: Poor; NA: Not Assessed; ND: Not Detailed.

\subsection{Illness Symptom PRO Instruments}

Fifteen illness symptom PRO instruments were selected.

Table 7 shows that sensitivity to change was not assessed for all these PRO instruments. Only the WHODAS-II [30] 32-item scale has high validity and reliability. PNS-Q [31], TEPS [32,33], RAS [34] and ReSUS [35] have high validity and average reliability. Only SHAPS [36] presents average validity and high reliability. The PPS scales [37-40] present average reliability and validity.

\subsection{Caregiver or Family PRO Instruments}

Successful treatment of schizophrenia often involves the patients being supported in their day-to-day functions by a family member or caregiver. This role carries a heavy responsibility but has received a disproportionately low level of attention. The level of support required varies widely from patient to patient, depending upon the severity of disease symptoms; for example, those with minimal levels of cognitive functioning often require fulltime supervision.

Families and caregivers need access to a support network, as their role in the patient's recovery is often long term and can be quite demanding physically, emotionally, financially, and in terms of time.

In this review, authors considered that instruments assessing caregiver's burden were PROs and not ObsROs, as they describe the respondent's burden, not the patient's burden.

Eight caregiver or family PRO instruments were selected. Table 8 shows that sensitivity to change was not assessed for any of these questionnaires. Both the ECI [20,41], a 66-item mental illness-specific scale, and the IEQ [42], a 31-item schizo-specific scale, have high va- lidity and reliability. Three other questionnaires pre- sent high validity and average reliability: the S-CGQoL [43], the PFBS [44] and the FAS [45,46].

\subsection{Other PROs for Patients}

Other questionnaires may also be used in the population of patients with schizophrenia. Table 9 includes twelve PRO instruments that are classified according to measured dimensions. The dimensions measured in these twelve questionnaires are: personality, social functioning, communication (patient/client), service satisfaction, and overall knowledge and understanding of schizophrenia. Both validity and reliability are high for the CSQ [47], an 8-item generic scale. The sensitivity to change was, however, not assessed. Both the SFS [48-50] and the WRSE-38 [51], a schizo-specific scale, show high reliability and average validity and sensitivity to change. The PAI [52] has high validity and average reliability. Sensitivity to change was not assessed for this questionnaire. The KASQ [53], a 25-items specific scale, shows acceptable psychometric properties with a high reliability and average validity and sensitivity to change.

\section{Discussion}

Health Technology Assessment (HTA) is intended to provide a bridge between the world of research and the world of clinical decision-making [54]. Today, both worlds are willing to better involve the patient, to account for patient's perspective on the same level as the clinician's perspective. Willke et al. report that PROs have a significant role in the development and evaluation of new medicines [55]. Hence, PRO instruments were developed to bring a clearer comprehension of the patient's self-described status. Indeed, "many aspects of 
Table 6. Treatment-related PRO instruments.

\begin{tabular}{|c|c|c|c|c|c|c|c|c|c|c|}
\hline \multicolumn{5}{|c|}{ General instrument characteristics } & \multicolumn{6}{|c|}{ Articles information } \\
\hline Name & Complete name & Generic/specific & $\begin{array}{l}\text { Number } \\
\text { of items }\end{array}$ & Dimensions & $\begin{array}{l}\text { Type of } \\
\text { study }\end{array}$ & Language & Validity I & Reliability & $\begin{array}{l}\text { Sensitivity } \\
\text { to change }\end{array}$ & Reference \\
\hline SRA & $\begin{array}{l}\text { The Subjects' } \\
\text { Response to } \\
\text { Antipsychotics } \\
\text { Questionnaire }\end{array}$ & $\begin{array}{l}\text { Antipsychotic } \\
\text { treated } \\
\text { patient-specific }\end{array}$ & 74 & $\begin{array}{l}\text { Response to } \\
\text { medication }\end{array}$ & Validation & NA & + & + & NA & $\begin{array}{l}\text { Wolters } \\
{[94]}\end{array}$ \\
\hline DAI & $\begin{array}{l}\text { The Drug Attitude } \\
\text { Inventory }\end{array}$ & NA & 30 & $\begin{array}{l}\text { Treatment } \\
\text { adherence }\end{array}$ & Mentioned & $\begin{array}{c}\text { NA } \\
\text { English } \\
\text { (USA) }\end{array}$ & NA & NA & NA & $\begin{array}{l}\text { Naber [19] } \\
\text { Awad [95] }\end{array}$ \\
\hline MARS & $\begin{array}{l}\text { The Medication } \\
\text { Adherence } \\
\text { Rating Scale }\end{array}$ & $\begin{array}{l}\text { Psychotic } \\
\text { disorder-specific }\end{array}$ & 10 & $\begin{array}{l}\text { Treatment } \\
\text { adherence }\end{array}$ & Validation & $\begin{array}{l}\text { English } \\
\text { (UK) }\end{array}$ & + & - & NA & Fialko [96] \\
\hline- & $\begin{array}{l}\text { The Self-Report } \\
\text { Scale Predictive of } \\
\text { Drug Compliance in } \\
\text { Schizophrenics }\end{array}$ & Schizophrenia & 30 & $\begin{array}{l}\text { Treatment } \\
\text { compliance }\end{array}$ & Validation & $\begin{array}{l}\text { English } \\
\text { (UK) }\end{array}$ & NA & NA & NA & Hogan [97] \\
\hline RAD-I & $\begin{array}{l}\text { Reasons for } \\
\text { Antipsychotic } \\
\text { Discontinuation/ } \\
\text { Continuation }\end{array}$ & Schizophrenia & ND & $\begin{array}{l}\text { Treatment } \\
\text { discontinuation/ } \\
\text { continuation }\end{array}$ & Mentioned & NA & NA & NA & NA & $\begin{array}{l}\text { Chen [98] } \\
\text { Nyhuis [99] }\end{array}$ \\
\hline LUNSERS & $\begin{array}{l}\text { The Liverpool } \\
\text { University } \\
\text { Neuroleptic Side } \\
\text { Effect Rating Scale }\end{array}$ & $\begin{array}{l}\text { Antipsychotic } \\
\text { treated } \\
\text { patient-specific }\end{array}$ & 51 & Side-effect & Validation & NA & ++ & ++ & NA & $\begin{array}{l}\text { Lambert } \\
\text { [29] }\end{array}$ \\
\hline SWAM & $\begin{array}{l}\text { The Satisfaction } \\
\text { with Antipsychotic } \\
\text { Medication scale }\end{array}$ & $\begin{array}{l}\text { Antipsychotic } \\
\text { treated } \\
\text { patient-specific }\end{array}$ & 33 & $\begin{array}{l}\text { Satisfaction } \\
\text { with medication }\end{array}$ & Validation & $\begin{array}{l}\text { English } \\
\text { (UK) }\end{array}$ & + & + & NA & $\begin{array}{l}\text { Rofail } \\
{[100]}\end{array}$ \\
\hline BEMIB & $\begin{array}{l}\text { The Brief Evaluation } \\
\text { of Medication } \\
\text { Influences } \\
\text { and Beliefs }\end{array}$ & $\begin{array}{l}\text { Antipsychotic } \\
\text { treated } \\
\text { patient-specific }\end{array}$ & 8 & $\begin{array}{l}\text { Medication } \\
\text { influence }\end{array}$ & Validation & NA & NA & NA & NA & $\begin{array}{l}\text { Dolder } \\
\text { [101] }\end{array}$ \\
\hline $\begin{array}{l}\text { UKU- } \\
\text { SERS- } \\
\text { Pat }\end{array}$ & $\begin{array}{l}\text { The Self Rating } \\
\text { Version of the } \\
\text { UKU Side Effect } \\
\text { Rating Scale }\end{array}$ & $\begin{array}{l}\text { Antipsychotic } \\
\text { treated } \\
\text { patient-specific }\end{array}$ & 48 & Side-effect & Validation & Swedish & + & NA & NA & $\begin{array}{l}\text { Lindström } \\
\text { [102] }\end{array}$ \\
\hline PETiT & $\begin{array}{l}\text { The Personal } \\
\text { Evaluation of } \\
\text { Transition in } \\
\text { Treatment Scale }\end{array}$ & NA & 30 & $\begin{array}{l}\text { Antipsychotic } \\
\text { treated } \\
\text { patient-specific }\end{array}$ & Mentioned & NA & NA & NA & NA & Naber [103] \\
\hline STAR-P & $\begin{array}{l}\text { The Scale to Assess } \\
\text { the Therapeutic } \\
\text { Relationship- } \\
\text { Patient Scale }\end{array}$ & $\begin{array}{l}\text { Antipsychotic } \\
\text { treated } \\
\text { patient-specific }\end{array}$ & 12 & $\begin{array}{l}\text { Therapeutic } \\
\text { relationship }\end{array}$ & Validation & Swedish & NA & NA & NA & $\begin{array}{l}\text { McGuire- } \\
\text { Snieckus } \\
\text { [103] }\end{array}$ \\
\hline
\end{tabular}

++: Robust; +: Moderate; -: Poor; NA: Not Assessed; ND: Not Detailed.

patients' experiences with illness, medication, and health care are best captured from PROs” [56].

The present study identified 70 PRO instruments that are used in patients with schizophrenia. Their quality assessment was based on a number of essential properties that define a high-quality instrument.

Moreover, a correctly developed PRO should satisfy psychometric properties: it has to be reliable and valid (including responsive to underlying change). Content validity is a critical aspect to be considered in that context [5]. Also, construct validity (whether the structure of the scale includes a single or multiple domains) should be thoroughly tested using appropriate methodology in order to justify the use of scale or summary scores. These properties were the basic criteria in our assessment of PRO instruments presented here.

In addition, these standards must be maintained throughout every target language population. In order to ensure that developmental standards are consistent in translated versions of a PRO instrument, the translated instrument undergoes a process known as linguistic validation in which the preliminary translation is adapted to 
Table 7. Illness symptom PRO instruments.

\begin{tabular}{|c|c|c|c|c|c|c|c|c|c|c|}
\hline \multicolumn{5}{|c|}{ General instrument characteristics } & \multicolumn{6}{|c|}{ Articles information } \\
\hline Name & Complete name & $\begin{array}{l}\text { Concept being } \\
\text { measured }\end{array}$ & $\begin{array}{l}\text { Generic/ } \\
\text { Specific }\end{array}$ & $\begin{array}{l}\text { Number } \\
\text { of items }\end{array}$ & $\begin{array}{l}\text { Type } \\
\text { of study }\end{array}$ & Language & Validity & Reliability & $\begin{array}{l}\text { Sensitivity } \\
\text { to change }\end{array}$ & Reference \\
\hline BSI & $\begin{array}{l}\text { The Brief Symptom } \\
\text { Inventory }\end{array}$ & $\begin{array}{l}\text { Symptom/ } \\
\text { diagnosis }\end{array}$ & NA & 53 & Validation & $\begin{array}{l}\text { English } \\
\text { (Australia) }\end{array}$ & + & NA & NA & Preston [104] \\
\hline PNS-Q & $\begin{array}{l}\text { The Positive and } \\
\text { Negative Symptoms } \\
\text { Questionnaire }\end{array}$ & $\begin{array}{l}\text { Symptom/ } \\
\text { diagnosis }\end{array}$ & Schizophrenia & 68 & Validation & $\begin{array}{l}\text { NA Hebrew } \\
\text { (Israel) }\end{array}$ & ++ & + & NA & Iancu [31] \\
\hline MIS & $\begin{array}{l}\text { The Magical } \\
\text { Ideation Scale }\end{array}$ & $\begin{array}{l}\text { Symptom/ } \\
\text { diagnosis }\end{array}$ & Schizophrenia & 68 & Validation & Turkish & NA & NA & NA & $\begin{array}{l}\text { Atbasoglu } \\
\text { [105] }\end{array}$ \\
\hline SHAPS & $\begin{array}{l}\text { The } \\
\text { Snaith-Hamilton } \\
\text { Pleasure Scale }\end{array}$ & Anhedonia & $\begin{array}{l}\text { Mental ill- } \\
\text { ness-specific }\end{array}$ & 14 & Validation & Dutch & + & ++ & NA & Franken [36] \\
\hline TEPS & $\begin{array}{l}\text { The Temporal } \\
\text { Experience } \\
\text { Pleasure Scale }\end{array}$ & Anhedonia & NA & 18 & Validation & French & ++ & + & NA & $\begin{array}{c}\text { Loas [32] } \\
\text { Favrod [33] }\end{array}$ \\
\hline ESI & $\begin{array}{l}\text { The Eppendorf } \\
\text { Schizophrenia } \\
\text { Inventory }\end{array}$ & $\begin{array}{l}\text { Subjective } \\
\text { experiences }\end{array}$ & Schizophrenia & 40 & Validation & $\begin{array}{l}\text { Italian, } \\
\text { German }\end{array}$ & NA & NA & NA & $\begin{array}{c}\text { Galeazzi [106] } \\
\text { Mass [107] }\end{array}$ \\
\hline FCQ & $\begin{array}{l}\text { The Frankfurt } \\
\text { Complaint } \\
\text { Questionnaire }\end{array}$ & $\begin{array}{l}\text { Subjective } \\
\text { experiences }\end{array}$ & $\begin{array}{l}\text { Psychotic- } \\
\text { specific }\end{array}$ & 98 & $\begin{array}{c}\text { Validation } \\
\bullet\end{array}$ & Spanish & NA & NA & NA & Cuesta [108] \\
\hline RAS & $\begin{array}{l}\text { The Recovery } \\
\text { Assessment Scale }\end{array}$ & Recovery & NA & 24 & Validation & $\begin{array}{l}\text { English } \\
\text { (Australia) }\end{array}$ & ++ & + & NA & $\begin{array}{l}\text { McNaught } \\
\text { [34] }\end{array}$ \\
\hline PPS-PhysAnh & $\begin{array}{l}\text { Psychosis } \\
\text { Proneness Scales- } \\
\text { Physical } \\
\text { Anhedonia Scale }\end{array}$ & $\begin{array}{l}\text { Physical } \\
\text { anhedonia }\end{array}$ & $\begin{array}{l}\text { Mental } \\
\text { illness-specific }\end{array}$ & 61 & Validation & $\begin{array}{l}\text { English } \\
\text { (USA) }\end{array}$ & + & + & NA & \\
\hline PPS-PerAb & $\begin{array}{l}\text { Psychosis Proneness } \\
\text { Scales-Perceptual } \\
\text { Aberration Scale }\end{array}$ & $\begin{array}{l}\text { S Perceptual } \\
\text { aberration }\end{array}$ & $\begin{array}{l}\text { Mental } \\
\text { illness-specific }\end{array}$ & 35 & Validation & $\begin{array}{l}\text { English } \\
\text { (USA) }\end{array}$ & + & + & NA & Horan [37] \\
\hline PPS-MIS & $\begin{array}{l}\text { Psychosis } \\
\text { Proneness Scales- } \\
\text { Magical Ideation } \\
\text { Scale }\end{array}$ & $\begin{array}{l}\text { Magical } \\
\text { ideation }\end{array}$ & $\begin{array}{l}\text { Mental } \\
\text { illness-specific }\end{array}$ & 30 & Validation & $\begin{array}{l}\text { English } \\
\text { (USA) }\end{array}$ & + & + & NA & $\begin{array}{c}\text { Assoury-Besse } \\
\text { [38] } \\
\text { Loas [39] } \\
\text { Scherbarth- } \\
\text { Roschmann }\end{array}$ \\
\hline PPS-ImpNon & $\begin{array}{l}\text { Psychosis Proneness } \\
\text { Scales-Impulsive } \\
\text { Nonconformity } \\
\text { Scale }\end{array}$ & $\begin{array}{l}\text { Impulsive } \\
\text { nonconformity }\end{array}$ & $\begin{array}{l}\text { Mental } \\
\text { illness-specific }\end{array}$ & 51 & Validation & $\begin{array}{l}\text { English } \\
\text { (USA) }\end{array}$ & + & + & NA & [40] \\
\hline PPS-SocAnh & $\begin{array}{l}\text { Psychosis Proneness } \\
\text { Scales-Social } \\
\text { Anhedonia Scale }\end{array}$ & $\begin{array}{l}\text { Social } \\
\text { anhedonia }\end{array}$ & $\begin{array}{l}\text { Mental } \\
\text { illness-specific }\end{array}$ & 40 & Validation & $\begin{array}{l}\text { English } \\
\text { (USA) }\end{array}$ & NA & NA & NA & \\
\hline ReSUS & $\begin{array}{l}\text { Reasons for } \\
\text { Substance Use in } \\
\text { Schizophrenia Scale }\end{array}$ & $\begin{array}{l}\text { Reasons for } \\
\text { substance use }\end{array}$ & Schizophrenia & 40 & Validation & $\begin{array}{l}\text { English } \\
\text { (UK) }\end{array}$ & ++ & + & NA & Gregg [35] \\
\hline WHODAS-II & $\begin{array}{l}\text { The WHO } \\
\text { Disability } \\
\text { Assessment } \\
\text { Schedule }\end{array}$ & Disability & NA & 32 & Validation & $\begin{array}{l}\text { English } \\
\text { (USA) }\end{array}$ & ++ & ++ & NA & McKibbin [30] \\
\hline
\end{tabular}

++: Robust; +: Moderate; - Poor; NA: Not Assessed; ND: Not Detailed.

reflect cultural and linguistic differences between diverse target populations.

We found that the TOOL is the most validated HRQoL PRO and appears to be the most appropriate scale for patients with schizophrenia, even if it is specific to a wider population (severe mental illness population). In addition, the SQLS-R4 has been translated into 52 languages through standardized procedures (i.e., forward translation, reconciliation, and back translation), which makes it a very interesting tool for large international comparison. 
Table 8. Caregiver or family PRO instruments.

\begin{tabular}{|c|c|c|c|c|c|c|c|c|c|c|}
\hline \multicolumn{5}{|c|}{ General instrument characteristics } & \multicolumn{6}{|c|}{ Articles information } \\
\hline Name & Complete name & $\begin{array}{l}\text { Concept being } \\
\text { measured }\end{array}$ & $\begin{array}{l}\text { Generic/ } \\
\text { Specific }\end{array}$ & $\begin{array}{l}\text { Number } \\
\text { of items }\end{array}$ & $\begin{array}{l}\text { Type of } \\
\text { study }\end{array}$ & Language & Validity & Reliability & $\begin{array}{l}\text { Sensitivity } \\
\text { to change }\end{array}$ & Reference \\
\hline QOF & $\begin{array}{l}\text { The Questionnaire on the } \\
\text { Opinions of the Family }\end{array}$ & $\begin{array}{l}\text { Opinion of } \\
\text { the Family }\end{array}$ & Schizophrenia & 35 & Validation & German & ++ & NA & NA & $\begin{array}{c}\text { Kallert } \\
{[109]}\end{array}$ \\
\hline S-CGQoL & $\begin{array}{l}\text { The Schizophrenia } \\
\text { Caregiver Quality of } \\
\text { Life Questionnaire }\end{array}$ & $\begin{array}{l}\text { Caregiver } \\
\text { quality of life }\end{array}$ & Schizophrenia & 25 & Validation & French & ++ & + & NA & $\begin{array}{l}\text { Richieri } \\
\text { [43] }\end{array}$ \\
\hline PFBS & $\begin{array}{l}\text { The Perceived Family } \\
\text { Burden Scale }\end{array}$ & $\begin{array}{l}\text { Family } \\
\text { burden }\end{array}$ & NA & 24 & Validation & $\begin{array}{l}\text { English } \\
\text { (Canada) }\end{array}$ & ++ & + & NA & $\begin{array}{l}\text { Levene } \\
\text { [44] }\end{array}$ \\
\hline ECI & $\begin{array}{l}\text { The Experience of } \\
\text { Caregiving Inventory }\end{array}$ & $\begin{array}{l}\text { Caregiver } \\
\text { quality of life }\end{array}$ & $\begin{array}{l}\text { Mental } \\
\text { illness-specific }\end{array}$ & 66 & Validation & Chinese & ++ & ++ & NA & $\begin{array}{l}\text { Naber [20] } \\
\text { Lau [41] }\end{array}$ \\
\hline- & $\begin{array}{l}\text { The Burden Inventory for } \\
\text { Relatives of Persons with } \\
\text { Psychotic Disturbances }\end{array}$ & $\begin{array}{l}\text { Family } \\
\text { burden }\end{array}$ & $\begin{array}{l}\text { Psychotic } \\
\text { disorder-specific }\end{array}$ & ND & Validation & Swedish & NA & NA & NA & $\begin{array}{c}\text { Hjärthag } \\
\text { [110] }\end{array}$ \\
\hline FEICS & $\begin{array}{l}\text { The Family Emotional } \\
\text { Involvement and } \\
\text { Criticism Scale }\end{array}$ & $\begin{array}{l}\text { Expressed } \\
\text { emotion }\end{array}$ & $\begin{array}{l}\text { Psychotic } \\
\text { disorder-specific }\end{array}$ & ND & Validation & German & NA & NA & NA & $\begin{array}{l}\text { Kronmüller } \\
\text { [111] }\end{array}$ \\
\hline FAS & $\begin{array}{l}\text { The Family } \\
\text { Attitude Scale }\end{array}$ & $\begin{array}{l}\text { Expressed } \\
\text { emotion }\end{array}$ & Schizophrenia & 30 & $\begin{array}{l}\text { Validation } \\
\text { Mentioned }\end{array}$ & $\begin{array}{l}\text { Japanese } \\
\text { Chinese }\end{array}$ & ++ & + & NA & $\begin{array}{l}\text { Fujita [45] } \\
\text { Li [46] }\end{array}$ \\
\hline IEQ & $\begin{array}{l}\text { The Involvement } \\
\text { Evaluation Questionnaire }\end{array}$ & $\begin{array}{l}\text { Caregiving } \\
\text { experience }\end{array}$ & Schizophrenia & 31 & Validation & Chinese & ++ & ++ & NA & $\begin{array}{l}\text { Chien } \\
\text { [42] }\end{array}$ \\
\hline
\end{tabular}

++: Robust; +: Moderate; -: Poor; NA: Not Assessed; ND: Not Detailed.

The BCIS seems to be the most widely used scale to assess patient insight, even though it was not evaluated for reliability and sensitivity to change. The BDI and BDI-II are used to assess depression for patients with schizophrenia, but the validity of the scales was not assessed for this population in particular. The LUNSERS questionnaire is the most widely used and validated questionnaire to evaluate side effects. The PPS is a complete set of scales to measures symptoms of schizophrenia, but it is very large; it is composed of 5 scales with several dimensions themselves. In practice, only a part of this battery of scales is used, depending on the objective of the study.

It is noteworthy that no instrument has been developed in line with FDA requirements: when developing a PRO instrument, sponsors should explain the development process of several concepts: items generation, choice of the data collection method, choice of response options, evaluation of patient understanding, development of format, instructions and training, identification of preliminary scoring of items and domains, assessment of respondent and administrator burden, confirmation of the conceptual framework and finalization of the instrument [5]. Despite the high number of PROs identified in this study, qualitative and quantitative analyzes available for these scales tended to significantly reduce the number of well-validated questionnaires. Nevertheless we recommend that future researchers pay attention not only to the basic critera mentioned above, especially high psychometric properties, but also to the ability of PRO instruments to provide the desired information, and to the application for which the instrument is intended (research, evaluation, individual patient care or population assessment).

A limitation of this study was the lack of exhaustivity of the publications: most articles selected via the search strategy were retrieved and extracted, but some of them were not available at the time of the analysis, and only abstract information was included.

In addition to the particular attention needed around psychometric proprieties, our recommendation for new PROs to be developed includes the necessity to demonstrate a relative independence from existing instruments. It is of importance to identify broader PRO outcomes that are relevant to clinicians and key stakeholders, identifying the best possible measures to assess these, capturing treatment benefit from the patient perspective so that patient, clinicans and key stakeholders gain a better insight to the risks and benefits of new treatments.

\section{Conclusions}

The aim of this review was to identify all PRO questionnaires used in the evaluation of patients with schizophrenia, and to evaluate the quality of these questionnaires based on their psychometric evidence.

The results show that the HRQoL PROs are the most 
Table 9. Other PRO instruments.

\begin{tabular}{|c|c|c|c|c|c|c|c|c|c|c|}
\hline \multicolumn{5}{|c|}{ General instrument characteristics } & \multicolumn{6}{|c|}{ Articles information } \\
\hline Name & Complete name & $\begin{array}{l}\text { Concept being } \\
\text { measured }\end{array}$ & $\begin{array}{l}\text { Generic/ } \\
\text { Specific }\end{array}$ & $\begin{array}{l}\text { Number } \\
\text { of items }\end{array}$ & $\begin{array}{l}\text { Type of } \\
\text { study }\end{array}$ & Language & Validity & Reliability & $\begin{array}{l}\text { Sensitivity } \\
\text { to change }\end{array}$ & Reference \\
\hline NEO-FFI & $\begin{array}{l}\text { The NEO Five } \\
\text { Factor Inventory }\end{array}$ & $\begin{array}{l}\text { Personality } \\
\text { measure }\end{array}$ & NA & 60 & Validation & $\begin{array}{l}\text { English } \\
\text { (USA) }\end{array}$ & NA & NA & NA & Bell [91] \\
\hline EPQ & $\begin{array}{l}\text { The Eysenck } \\
\text { Personality } \\
\text { Questionnaire }\end{array}$ & $\begin{array}{l}\text { Personality } \\
\text { measure }\end{array}$ & NA & 90 & Validation & $\begin{array}{l}\text { English } \\
\text { (USA) }\end{array}$ & NA & NA & NA & Bell [91] \\
\hline BORRTI & $\begin{array}{l}\text { The Bell Object } \\
\text { Relations and } \\
\text { Reality Testing } \\
\text { Inventory }\end{array}$ & $\begin{array}{l}\text { Personality } \\
\text { measure }\end{array}$ & NA & 90 & Validation & $\begin{array}{l}\text { English } \\
\text { (USA) }\end{array}$ & NA & NA & NA & Bell [91] \\
\hline MMPI-2 & $\begin{array}{l}\text { The Minnesota } \\
\text { Multiphasic } \\
\text { Personality } \\
\text { Inventory-Revised }\end{array}$ & $\begin{array}{l}\text { Personality } \\
\text { measure }\end{array}$ & $\begin{array}{l}\text { Psychopathology- } \\
\text { specific }\end{array}$ & ND & Validation & Korean & + & NA & NA & Park [112] \\
\hline PAI & $\begin{array}{l}\text { The Personality } \\
\text { Assessment } \\
\text { Inventory }\end{array}$ & $\begin{array}{l}\text { Personality } \\
\text { measure }\end{array}$ & $\begin{array}{l}\text { Psychopathology- } \\
\text { specific }\end{array}$ & 344 & Validation & $\begin{array}{l}\text { English } \\
\text { (Australia) }\end{array}$ & ++ & + & NA & Boyle [52] \\
\hline SFS & $\begin{array}{l}\text { The Social } \\
\text { Functioning Scale }\end{array}$ & $\begin{array}{l}\text { Social } \\
\text { functioning }\end{array}$ & NA & 15 & Validation & $\begin{array}{c}\text { English } \\
\text { (UK, USA), } \\
\text { Norwegian }\end{array}$ & + & ++ & + & $\begin{array}{c}\text { Birchwood } \\
\text { [48] } \\
\text { Hellvin } \\
\text { [49] } \\
\text { Leifker } \\
\text { [50] }\end{array}$ \\
\hline 2-COM & $\begin{array}{l}\text { The Two-Way } \\
\text { Communication } \\
\text { Checklist }\end{array}$ & $\begin{array}{l}\text { Communication } \\
\text { patient/clinician }\end{array}$ & Schizophrenia & 20 & Validation & $\begin{array}{c}\text { NA } \\
\text { English } \\
\text { (UK) }\end{array}$ & ++ & NA & NA & $\begin{array}{c}\text { Naber [20] } \\
\text { Van Os } \\
\text { [113] }\end{array}$ \\
\hline ASC-SR & $\begin{array}{l}\text { The Approaches to } \\
\text { Schizophrenia } \\
\text { Communication- } \\
\text { Self-Report }\end{array}$ & $\begin{array}{l}\text { Communication } \\
\text { patient/clinician }\end{array}$ & Schizophrenia & ND & Validation & $\begin{array}{l}\text { English } \\
\text { (USA) }\end{array}$ & NA & NA & NA & $\begin{array}{c}\text { Dassori } \\
\text { [114] }\end{array}$ \\
\hline VSSS-54F & $\begin{array}{l}\text { The Verona } \\
\text { Service } \\
\text { Satisfaction } \\
\text { Scale-Patient } \\
\text { Version }\end{array}$ & $\begin{array}{l}\text { Communication } \\
\text { patient/clinician }\end{array}$ & NA & 54 & Validation & $\begin{array}{l}\text { French, } \\
\text { Greeck }\end{array}$ & NA & NA & NA & $\begin{array}{c}\text { Corbiere } \\
\text { [115] } \\
\text { Bletsa } \\
\text { [116] }\end{array}$ \\
\hline CSQ-8 & $\begin{array}{l}\text { The Client } \\
\text { Satisfaction } \\
\text { Questionnaire }\end{array}$ & $\begin{array}{l}\text { Services } \\
\text { satisfaction }\end{array}$ & Generic & 8 & Validation & NA & ++ & ++ & NA & $\begin{array}{c}\text { Larsen } \\
\text { [47] }\end{array}$ \\
\hline WRSE-38 & $\begin{array}{l}\text { The } \\
\text { Work-Related } \\
\text { Subjective } \\
\text { Experience scale }\end{array}$ & $\begin{array}{l}\text { Services } \\
\text { satisfaction }\end{array}$ & Schizophrenia & 38 & Validation & $\begin{array}{l}\text { English } \\
\text { (Australia) }\end{array}$ & + & ++ & + & $\begin{array}{l}\text { Waghorn } \\
\text { [51] }\end{array}$ \\
\hline KASQ & $\begin{array}{l}\text { The Knowledge } \\
\text { about } \\
\text { Schizophrenia } \\
\text { Questionnaire }\end{array}$ & $\begin{array}{l}\text { Overall knowledge } \\
\text { and understanding } \\
\text { of schizophrenia }\end{array}$ & $\begin{array}{l}\text { Schizophrenia- } \\
\text { specific }\end{array}$ & 25 & Validation & $\begin{array}{l}\text { English } \\
\text { (India) }\end{array}$ & + & ++ & + & $\begin{array}{c}\text { Ascher- } \\
\text { Svanum } \\
\text { [53] }\end{array}$ \\
\hline
\end{tabular}

++: Robust; +: Moderate; -: Poor; NA: Not Assessed; ND: Not Detailed.

numerous and the best validated in schizophrenia. Although selection of PROs should be based on the rigor of their psychometric properties, researchers should also focus on their ability to respond to objectives of their study.

As schizophrenia is a multi-dimensional mental illness, we argue that today, the validity of PRO questionnaires is insufficient to obtain a clear comprehension of the condition and treatment effects in patients with schizophrenia. Thus, we think that new PRO instruments in schizophrenia should be developed in order to reach the full spectrum of possible outcomes related to the disease 
and its treatment.

\section{REFERENCES}

[1] D. T. Y. Tsoi, M. D. Hunter and P. W. R. Woodruff, "History, Aetiology, and Sypmtomatology of Schizophrenia,” Psychiatry, Vol. 7, No. 10, 2008, pp. 404-409. http://dx.doi.org/10.1016/j.mppsy.2008.07.010

[2] S. Saha, D. Chant, J. Welham and J. McGrath, "A Systematic Review of the Prevalence of Schizophrenia,” PLOS Medicine, Vol. 2, No. 5, 2005, p. e141. http://dx.doi.org/10.1371/journal.pmed.0020141

[3] “Schizophrenia,” NIH Publication No. 09-3517, Revised 2009.

[4] R. McCabe, M. Saidi and S. Priebe, "Patient-Reported Outcomes in Schizophrenia,” The British Journal of Psychiatry, Vol. 191, 2007, pp. s21-s28. http://dx.doi.org/10.1192/bjp.191.50.s21

[5] US Department of Health and Human Services, Food and Drug Administration, Center for Drug Evaluation and Research (CDER), Center for Biologics Evaluation and Research (CBER), Center for Devices and Radiological Health (CDRH), "Guidance for Industry Patient-Reported Outcome Measures: Use in Medical Product Development to Support Labeling Claims,” December 2009.

[6] L. J. Schmidt, A. M. Garratt and R. Fitzpatrick, "Instruments for Mental Health: A Review Report from the Patient-Reported Health Instruments Group (Formerly the Patient-Assessed Health Outcomes Programme) to the Department of Health,” September 2000.

[7] R. Hunter, R. Cameron and J. Norrie, "Using Patient-Reported Outcomes in Schizophrenia: The Scottish Schizophrenia Outcomes Study," Psychiatric Services, Vol. 60, No. 2, 2009, pp. 240-245.

http://dx.doi.org/10.1176/appi.ps.60.2.240

[8] R. Fitzpatrick, A. E. Fletcher, S. M. Gore, D. Jones, D. J. Spiegelhalter and D. R. Cox, "Quality of Life Measures in Health Care,” British Medical Journal, Vol. 305, No. 6861, 1992, pp. 1074-1077. http://dx.doi.org/10.1136/bmj.305.6861.1074

[9] MRC, "Patient Reported Outcome Measures (PROMs): Identifying UK Research Priorities,” Medical Research Council, London, 2009.

[10] M. Nussbaum and A. Sen, “The Quality of Life,” Clarendon Press, Oxford, 1993.

[11] D. Gregory, R. Johnston, G. Pratt, M. Watts and S. Whatmore, "Quality of Life. Dictionary of Human Geography," 5th Edition, Wiley-Blackwell, Oxford, 2009.

[12] B. Spilker, "Quality of Life and Pharmacoeconomics in Clinical Trials,” 2nd Edition, Lippincott-Raven, Philadelphia, 1996.

[13] P. A. Ganz, "Impact of Quality of Life Outcomes on Clinical Practice,” Oncology (Williston Park), Vol. 9, Supplement 11, 1995, pp. 61-65.

[14] Centers for Disease Control and Prevention, "HealthRelated Quality of Life (HRQOL),” 2011. http://www.cdc.gov/hrqol/
[15] A. L. Montejo, J. C. Lauffer, J. Cuervo, P. Rebollo, L. Cordero, T. Diez and J. Maurino, "Validation of a Specific Measure to Assess Healthrelated Quality of Life in Patients with Schizophrenia and Bipolar Disorder: The 'Tolerability and Quality of Life’ (TOOL) Questionnaire,' Annals of General Psychiatry, Vol. 10, 2011 , p. 6.

[16] A. Montejo, J. CorreasLauffer, F. Porras, T. Martin, P. Ruiz Carrasco, L. Cordero, T. Diez and J. Maurino, "Spanish Validation of Tool Questionnaire: A New Instrument to Assess Quality of Life in Patients with Schizophrenia and Bipolar Disorder,” European Psychiatry, Vol. 24, Suppl. 1, 2009, p. S947.

[17] L. Jönsson, A. Lang and E. Lindström, “TOOL: MultiAttribute Utility Function Reflecting Patient Experience of Side Effects to Antipsychotic Therapy,” ISPOR 12th Annual European Congress, Paris, 24-27 October 2009.

[18] C. Luis, J. Maurino, A. L. Montejo, P. Rebollo, J. Cuervo, T. Diez, M. Tafalla and R. Hernandez, "The Spanish Version of the TOOL Questionnaire: A Useful Measure for Evaluating the HRQOL and Utilities from Schizophrenic and Bipolar Patients,” (PMH43) ISPOR 11th Annual European Congress, Athens, 8-11 November, 2008.

[19] D. Naber, S. Moritz, M. Lambert, F. G. Pajonk, R. Holzbach, R. Mass and B. Andresen, "Improvement of Schizophrenic Patients' Subjective Well-Being under Antipsychotic Drugs,” Schizophrenia Research, Vol. 50, No. 1, 2001, pp. 79-88. http://dx.doi.org/10.1016/S0920-9964(00)00166-3

[20] D. Naber and A. Vita, "Tools for Measuring Clinical Effectiveness,” European Neuropsychopharmacology, Vol. 14, Suppl. 4, 2004, pp. S435-S444. http://dx.doi.org/10.1016/j.euroneuro.2004.08.002

[21] Y. W. Lee, J. H. Kim, J. H. Ann, S. E. Cho, J. Lee, M. K. Kim, S. J. Cho, I. H. Cho, S. J. Kim, Y. J. Lee and S. M. Bae, "Subjective Well-being in Patients with Schizophrenia Treated with Atypical Antipsychotics: The Impact of Psychopathology and Adverse Drug Effects,” Clinical Psychopharmacology and Neuroscience, Vol. 3, 2010, pp. 149-155.

[22] K. Jaspers, “General Psychopathology,” Manchester University Press, Manchester, 1959.

[23] A. Lewis, “The Psychopathology of Insight," Journal of Medical Psychology, Vol. 14, No. 4, 1934, pp. 332-348. http://dx.doi.org/10.1111/j.2044-8341.1934.tb01129.x

[24] W. T. Carpenter Jr., J. S. Strauss and J. J. Bartko, "Flexible System for the Diagnosis of Schizophrenia: Report from the WHO International Pilot Study of Schizophrenia,” Science, Vol. 182, No. 4118, 1973, pp. 1275-1278. http://dx.doi.org/10.1126/science.182.4118.1275

[25] X. F. Amador, M. Flaum, N. C. Andreasen, D. H. Strauss, S. A. Yale, S. C. Clark and J. M. Gorman, "Awareness of Illness in Schizophrenia and Schizoaffective and Mood Disorders," Archives of General Psychiatry, Vol. 51, No. 10, 1994, pp. 826-836. http://dx.doi.org/10.1001/archpsyc.1994.0395010007400 $\underline{7}$

[26] A. David, A. Buchanan, A. Reed and O. Almeida, "The Assessment of Insight in Psychosis,” The British Journal of Psychiatry, Vol. 161, 1992, pp. 599-602. 
http://dx.doi.org/10.1192/bjp.161.5.599

[27] N. Hayashi, M. Yamashina and Y. Igarashi, “Awareness of Being a Patient and Its Relevance to Insight Into Illness in Patients With Schizophrenia,” Comprehensive Psychiatry, Vol. 40, No. 5, 1999, pp. 377-385. http://dx.doi.org/10.1016/S0010-440X(99)90144-X

[28] A. T. Beck, E. Baruch, J. M. Balter, R. A. Steer and D. M. Warman, “A New Instrument for Measuring Insight: The Beck Cognitive Insight Scale,” Schizophrenia Research, Vol. 68, No. 2, 2004, pp. 319-329. http://dx.doi.org/10.1016/S0920-9964(03)00189-0

[29] T. J. Lambert, N. Cock, S. J. Alcock, D. L. Kelly and R. R. Conley, "Measurement of Antipsychotic-Induced Side Effects: Support for the Validity of a Self-Report (LUNSERS) versus Structured Interview (UKU) Approach to Measurement," Human Psychopharmacology, Vol. 18, No. 5, 2003, pp. 405-411.

http://dx.doi.org/10.1002/hup.495

[30] C. McKibbin, T. L. Patterson and D. V. Jeste, “Assessing Disability in Older Patients with Schizophrenia. Results from the WHODAS-II," The Journal of Nervous and Mental Disease, Vol. 192, No. 6, 2004, pp. 405-413. http://dx.doi.org/10.1097/01.nmd.0000130133.32276.83

[31] I. Iancu, A. Poreh, B. Lehman, E. Shamir and M. Kotler, "The Positive and Negative Symptoms Questionnaire: A Self-Report Scale in Schizophrenia,” Comprhensive Psychiatry, Vol. 46, No. , 2005, pp. 61-66. http://dx.doi.org/10.1016/j.comppsych.2004.07.014

[32] G. Loas, J. L. Monestes, A. Ameller, M. Bubrovszky, V. Yon, J. Wallier, S. Berthoz and M. Corcos, "Traduction et Etude de Validation de la Version Française de L'échelle d’Expérience Temporelle du Plaisir,” Annales MédicoPsychologiques, Vol. 167, No. 9, 2008, pp. 1-17.

[33] J. Favrod, F. Ernst, F. Giuliani and C. Bonsack, "Validation of the Temporal Experience of Pleasure Scale (TEPS) in a French-Speaking Environment," L'Encéphale, Vol. 35, No. 3, 2008, pp. 241-248. http://dx.doi.org/10.1016/j.encep.2008.02.013

[34] M. McNaught, P. Caputi, L. G. Oades and F. P. Deane, "Testing the Validity of the Recovery Assessment Scale Using an Australian Sample," Australian and New Zealand Journal of Psychiatry, Vol. 41, No. 5, 2007, pp. 450-457. http://dx.doi.org/10.1080/00048670701264792

[35] L. Gregg, C. Barrowclough and G. Haddock, "Development and Validation of a Scale for Assessing Reasons for Substance Use in Schizophrenia: The ReSUS Scale,” Addictive Behaviors, Vol. 34, No. 10, 2009, pp. 830-837. http://dx.doi.org/10.1016/j.addbeh.2009.03.004

[36] I. H. Franken, E. Rassin and P. Muris, "The Assessment of Anhedonia in Clinical and Non-Clinical Populations: Further Validation of the Snaith-Hamilton Pleasure Scale (SHAPS)," Journal of Affective Disorders, Vol. 99, No. 1, 2007, pp. 83-89.

http://dx.doi.org/10.1016/j.jad.2006.08.020

[37] W. P. Horan, S. P. Reise, K. L. Subotnik, J. Ventura and K. H. Nuechterlein, "The Validity of Psychosis Proneness Scales as Vulnerability Indicators in Recent-Onset Schizophrenia Patients," Schizophrenia Research, Vol. 100, No. 1, 2008, pp. 224-236. http://dx.doi.org/10.1016/j.schres.2007.12.469

[38] F. Assouly-Besse, S. Dollfus and M. Petit, “Traductionfrançaise des Questionnaires d'Anhédoniesociale et Physique de Chapman: Validation de la Traductionfrançaise à Partir de Témoins et de Patients Schizophrènes," L'Encéphale, Vol. 21, 2012, pp. 273-284.

[39] G. Loas and P. Boyer, "Evaluation of Anhedonia in Psychopathology: Second Study of the Validation of the French Version of the Chapman and Chapman Physical Anhedonia Scale. Study of 356 Persons,” Annales MédicoPsychologiques, Vol. 152, No. 4, 1994, pp. 256-259.

[40] P. Scherbarth-Roschmann and M. Hautzinger, "Psychosis Proneness and Clinical Psychopathology: Positive and Negative Symptoms,” Zeitschrift Für Klinische Psychologie, Vol. 20, 1991, pp. 371-378.

[41] D. Y. K. Lau and A. H. T. Pang, "Validation of the Chinese Version of Experience of Cairegiving Inventory in Caregivers of Persons Suffering from Severe Mental Disorders," Hong Kong Journal of Psychiatry, Vol. 17, No. 1, 2007, pp. 24-31.

[42] W. T. Chien and S. W. Chan, "Validation of the Chinese Version of the Involvement Evaluation Questionnaire," Hong Kong Journal of Psychiatry, Vol. 18, No. 1, 2008, pp. 6-14.

[43] R. Richieri, L. Boyer, G. Reine, A. Loundou, P. Auquier, C. Lançon and M. C. Simeoni, "The Schizophrenia Caregiver Quality of Life Questionnaire (S-CGQoL): Development and Validation of an Instrument to Measure Quality of Life of Caregivers of Individuals with Schizophrenia," Schizophrenia Research, Vol. 126, No. 1, 2011, pp. 192201. http://dx.doi.org/10.1016/j.schres.2010.08.037

[44] J. E. Levene, W. J. Lancee and M. V. Seeman, “The Perceived Family Burden Scale: Measurement and Validation,” Schizophrenia Research, Vol. 22, No. 2, 1996, pp. 151-157. http://dx.doi.org/10.1016/S0920-9964(96)00071 $\underline{-0}$

[45] H. Fujita, S. Shimodera, Y. Izumoto, S. Tanaka, M. Kii, Y. Mino and S. Inoue, "Family Attitude Scale: Measurement of Criticism in the Relatives of Patients with Schizophrenia in Japan,” Psychiatry Research, Vol. 110, No. 3, 2002, pp. 273-280. http://dx.doi.org/10.1016/S0165-1781(02)00108-7

[46] Z. Li and D. Arthur, "A Study of Three Measures of Expressed Emotion in a Sample of Chinese Families of a Person with Schizophrenia," Journal of Psychiatric and Mental Health Nursing, Vol. 12, No. 4, 2005, pp. 431-438. http://dx.doi.org/10.1111/j.1365-2850.2005.00858.x

[47] D. L. Larsen, C. C. Attkisson, W. A. Hargreaves and T. D. Nguyen, "Assessment of Client/Patient Satisfaction: Development of a General Scale," Evaluation and Program Planning, Vol. 2, No. 3, 1979, pp. 197-207. http://dx.doi.org/10.1016/0149-7189(79)90094-6

[48] M. Birchwood, J. Smith, R. Cochrane, S. Wetton and S. Copestake, "The Social Functioning Scale. The Development and Validation of a New Scale of Social Adjustment for Use in Family Intervention Programmes with Schizophrenic Patients,” The British Journal of Psychiatry, Vol. 157, 1990, pp. 853-859. http://dx.doi.org/10.1192/bjp.157.6.853 
[49] T. Hellvin, K. Sundet, A. Vaskinn, C. Simonsen, T. Ueland, O. A. Andreassen and I. Melle, "Validation of the Norwegian version of the Social Functioning Scale (SFS) for Schizophrenia and Bipolar Disorder," Scandinavian Journal of Psychology, Vol. 51, No. 6, 2010, pp. 525-533. http://dx.doi.org/10.1111/j.1467-9450.2010.00839.x

[50] F. R. Leifker, T. L. Patterson, R. K. Heaton and P. D. Harvey, "Validating Measures of Real-World Outcome: The Results of the VALERO Expert Survey and RAND Panel,” Schizophrenia Bulletin, Vol. 37, No. 2, 2009, pp. 334-343.

[51] G. Waghorn, D. Chant and R. King, "Work-related Subjective Experiences among Community Residents with Schizoaffective Disorder,” Australian and New Zealand Journal of Psychiatry, Vol. 39, No. 4, 2005, pp. 288-299. http://dx.doi.org/10.1080/j.1440-1614.2005.01567.x

[52] G. J. Boyle and T. J. Lennon, "Examination of the Reliability and Validity of the Personality Assessment Inventory," Journal of Psychopathology and Behavioral Assessment, Vol. 16, No. 3, 1994, pp. 173-187. http://dx.doi.org/10.1007/BF02229206

[53] H. Ascher-Svanum, "Development and Validation of a Measure of Patients' Knowledge about Schizophrenia," Psychiatric Services, Vol. 50, No. 4, 1999, pp. 561-563.

[54] R. N. Battista, "The scientific Basis of Health Services," BMJ Publishing Group, London, 1996.

[55] R. J. Willke, L. B. Burke and P. Erickson, "Measuring Treatment Impact: A Review of Patient-Reported Outcomes and Other Efficacy Endpoints in Approved Product Labels," Controlled Clinical Trials, Vol. 25, No. 6, 2004, pp. 535-552. http://dx.doi.org/10.1016/j.cct.2004.09.003

[56] N. E. Rothrock, K. A. Kaiser and D. Cella, "Developing a Valid Patient-Reported Outcome Measure,” Clinical Pharmacology \& Therapeutics, Vol. 90, No. 5, 2011, pp. 737742. http://dx.doi.org/10.1038/clpt.2011.195

[57] M. Terre and K. D. Blanche, "Research in Practice: Applied Methods for the Social Sciences,” 2nd Edition, UTC Press, 2008.

[58] M. J. Miller, "Reliability and Validity,” RES 600: Graduate Research Methods, Western International University.

[59] M. Rothman, L. Burke, P. Erickson, et al., "Use of Existing Patient-Reported Outcome (PRO) Instruments and Their Modification: The ISPOR Good Research Practices for Evaluating and Documenting Content Validity for the Use of Existing Instruments and Their Modification PRO Task Force Report,” Value Health, Vol. 12, No. 8, 2009, pp. $1075-1083$. http://dx.doi.org/10.1111/j.1524-4733.2009.00603.x

[60] S. N. Haynes, D. C. S. Richard and E. S. Kubany, "Content Validity in Psychological Assessment: A Functional Approach to Concepts and Methods," Psychological Assessment, Vol. 7, No. 3, 1995, pp. 238-247. http://dx.doi.org/10.1037/1040-3590.7.3.238

[61] M. H. Frost, B. B. Reeve, A. M. Liepa, J. W. Stauffer and R. D. Hays, "Mayo/FDA Patient-Reported Outcomes Consensus Meeting Group. What Is Sufficient Evidence for the Reliability and Validity of Patient-Reported Out- come Measures?” Value Health, Vol. 10, Supplement 2, 2007, pp. S94-S105.

http://dx.doi.org/10.1111/j.1524-4733.2007.00272.x

[62] M. Hersen, "Clinician's Handbook of Adult Behavioral Assessment,” Elsevier Academic Press, San Diego, 2006, p. 32.

[63] P. W. Stratford, J. M. Binkley, D. L. Riddle and G. H. Guyatt, "Sensitivity to change of the Roland-Morris Back Pain Questionnaire: Part 1,” Physical Therapy, Vol. 78, 1998, pp. 1186-1196.

[64] J. Carlson, S. Ochoa, J. M. Haro, G. Escartín, M. Ahuir, A. Gutierrez-Zotes, M. Salamero, J. Valero, S. Cañizares, M. Bernardo, J. Cañete and P. Gallo, "Adaptation and Validation of the Quality-of-Life Scale: Satisfaction with Life Domains Scale by Baker and Intagliata," Comprehensive Psychiatry, Vol. 50, No. 1, 2009, pp. 76-80. http://dx.doi.org/10.1016/j.comppsych.2008.05.008

[65] C. Lançon, G. Reine, M. C. Simeoni, V. Aghababian and P. Auquier, "Développement et Validation d'un Instrument d'Auto-Évaluation de la Qualité de vie des Patients Souffrant de Schizophrénie: La S-QoL," L'Encéphale, Vol. 33, No. 3, 2007, pp. 277-284. http://dx.doi.org/10.1016/S0013-7006(07)92040-0

[66] P. Auquier, M. C. Simeoni, C. Sapin, G. Reine, V. Aghababian, J. Cramer and C. Lançon, "Development and Validation of a Patient-Based Health-Related Quality of Life Questionnaire in Schizophrenia: The S-QoL,” Schizophrenia Research, Vol. 63, No. 1-2, 2003, pp. 137-149. http://dx.doi.org/10.1016/S0920-9964(02)00355-9

[67] C. Sapin, P. Auquier, S. Robitail and M. C. Simeoni, "Preliminary Validation of the English Version of the Schizophrenia Quality of Life (S-QoL) Scale,” ISPOR Tenth Annual European Congress, Dublin, 2007.

[68] J. Caron, M. Corbière, C. Mercier, P. Diaz, N. Ricard and A. Lesage, "The Construct Validity of the Client Questionnaire of the Wisconsin Quality of Life Index-A Cross-Validation Study," International Journal of Methods in Psychiatric Research, Vol. 12, No. 3, 2013, pp. 128-138.

[69] P. Diaz, C. Mercier, R. Hachey, J. Caron and G. Boyer, "An Evaluation of Psychometric Properties of the Client's Questionnaire of the Wisconsin Quality of Life IndexCanadian Version (CaW-QLI),” Quality of Life Research, Vol. 8, No. 6, 1999, pp. 509-514. http://dx.doi.org/10.1023/A:1008970321690

[70] G. Wilkinson, B. Hesdon, D. Wild, R. Cookson, C. Farina, V. Sharma, R. Fitzpatrick and C. Jenkinson, "Self-Report Quality of Life Measure for People with Schizophrenia: The SQLS,” The British Journal of Psychiatry, Vol. 177, 2011, pp. 42-46. http://dx.doi.org/10.1192/bjp.177.1.42

[71] Y. Kaneda, A. Imakura, A. Fujii and T. Ohmori, "Schizophrenia Quality of Life Scale: Validation of the Japanese Version,” Psychiatry Research, Vol. 113, No. 1, 2002, pp. 107-113. http://dx.doi.org/10.1016/S0165-1781(02)00240-8

[72] N. Luo, B. K. Seng, F. Xie, S. C. Li and J. Thumboo, "Psychometric Evaluation of the Schizophrenia Quality of Life Scale (SQLS) in English- and Chinese-Speaking Asians in 
Singapore,” Quality of Life Research, Vol. 17, No. 1, 2007, pp. 115-122.

http://dx.doi.org/10.1007/s11136-007-9278-1

[73] P. J. Kuo, M. J. Chen-Sea, R. B. Lu, M. S. Chung, C. C. Kuo, W. C. Huang and H. I. Ma. "Validation of the Chinese Version of the Schizophrenia Quality of Life Scale Revision 4 (SQLS-R4) in Taiwanese Patients with Schizophrenia," Quality of Life Research, Vol. 16, No. 9, 2007, pp. 1533-1538. http://dx.doi.org/10.1007/s11136-007-9262-9

[74] L. Nadalet, F. S. Kohl, D. Pringuey and F. Berthier, "Validation of a Subjective Quality of Life Questionnaire (S.QUA.LA) in Schizophrenia,” Schizophrenia Research, Vol. 76, No. 1, 2005, pp. 73-81.

http://dx.doi.org/10.1016/j.schres.2004.09.017

[75] A. Pitkänen, M. Välimäki, J. Endicott, J. Katajisto, T. Luukkaala, M. Koivunen, L. Kuosmanen and H. Hätönen, "Assessing Quality of Life in Patients with Schizophrenia in an Acute Psychiatric Setting: Reliability, Validity and Feasibility of the EQ-5D and the Q-LES-Q," Nordic Journal of Psychiatry, Vol. 66, No. 1 , 2012, pp. 19-25. http://dx.doi.org/10.3109/08039488.2011.593099

[76] M. Ritsner, R. Kurs, A. Gibel, Y. Ratner and J. Endicott, "Validity of an Abbreviated Quality of Life Enjoyment and Satisfaction Questionnaire (Q-LES-Q-18) for schizophrenia, Schizoaffective, and Mood Disorder Patients," Quality of Life Research, Vol. 14, No. 7, 2005, pp. 1693-1703. http://dx.doi.org/10.1007/s11136-005-2816-9

[77] L. Prieto, D. Novick, J. A. Sacristán, E. T. Edgell and J. Alonso, "SOHO Study Group. A Rasch Model Analysis to Test the Cross-Cultural Validity of the EuroQoL-5D in the Schizophrenia Outpatient Health Outcomes Study," Acta Psychiatrica Scandinavica, Vol. 107, No. 416, 2003, pp. 24-29.

http://dx.doi.org/10.1034/j.1600-0447.107.s416.6.x

[78] L. Prieto, J. A. Sacristán, J. A. Hormaechea, A. Casado, X. Badia and J. C. Gómez, "Psychometric Validation of a Generic Health-Related Quality of Life Measure (EQ-5D) in a Sample of Schizophrenic Patients," Current Medical Research and Opinion, Vol. 20, No. 6, 2004, pp. 827-835. http://dx.doi.org/10.1185/030079904125003674

[79] N. Luo, B. K. Seng, J. Thumboo, D. Feeny and S. C. Li, "A study of the Construct Validity of the Health Utilities Index Mark 3 (HUI3) in Patients with Schizophrenia," Quality of Life Research, Vol. 15, No. 5, 2006, pp. 889-898.

[80] P. Martin, H. Caci, J. M. Azorin, J. Daléry, M. C. HardyBaylé, D. Etienne, D. Gérard, C. S. Peretti and S. O. L. Grouped'étude, “A New Patient Focused Scale for Measuring Quality of Life in Schizophrenic Patients: The Schizophrenia Quality of Life Scale (SOL),” L'Encephale, Vol. 31, No. 5, 2005 , pp. 559-566.

http://dx.doi.org/10.1016/S0013-7006(05)82415-7

[81] D. Laliberte-Rudman, L. Hoffman, E. Scott and R. Renwick, "Quality of Life for Individuals with Schizophrenia: Validating an Assessment That Addresses Client Concerns and Occupational Issues," Occupational Therapy Journal of Research: Occupation, Participation and Health, Vol. 24, No. 1, 2004, pp. 13-21.

[82] J. Barr, G. Schumacher and S. Ohman, "Comparison of Outcomes Reported by Individuals with Schizophrenia
Residing in the Community and Objective Outcomes Reported by Caregivers," ISPOR 10th Annual International Meeting, Washington, DC, 20-23 October 2005.

[83] J. Barr, G. Schumacher, S. Ohman and E. Mason, "Patient-Reported Outcomes: Do They Agree with Objective Caregiver-Reported Outcomes for Individuals with Schizophrenia Residing in the Community?” ISPOR 7th Annual European Congress, Hamburg, 24-26 October 2004.

[84] J. T. Barr, G. E. Schumacher, E. Mason, S. Ohman and A. Hanson, "SOAP-51: A Quality of Life Survey for Community-Residing Individuals with Schizophrenia,” ISPOR 4th Annual European Congress, Cannes, 11-13 November 2001.

[85] J. Adams, C. Le Reun, S. Crowley, V. Nand, A. Eggleston and R. Schrover, "Valuation of Schizophrenia-Related Health States by the General Population Using the AQoL, Time Trade-Off and Visual Analogue Scales,” ISPOR 10th Annual International Meeting, Washington, DC, 1518 May 2005.

[86] J. Adams, C. Le Reun, S. Crowley, V. Nand and A. Eggleston, "Schizophrenia and Quality of Life Assessments," (MH3) ISPOR 7th Annual European Congress, Hamburg, 24-26 October 2004.

[87] A. Ruppert, R. Waldeck, P. Cislo, K. Punger, T. Iwamoto, Y. Yuan, U. Ösby, S. Bristol-Myers and B. Waterloo, "Health-Related Quality of Life in Outpatients with Schizophrenia in Singaphore," (PMH17) ISPOR 6th Annual European Congress, Hamburg, 9-11 November 2003.

[88] P. Pedrelli, J. R. McQuaid, E. Granholm, T. L. Patterson, F. McClure, A. T. Beck and D. V. Jeste, "Measuring Cognitive Insight in Middle-Aged and Older Patients with Psychotic Disorders," Schizophrenia Research, Vol. 71, No. 2, 2004, pp. 297-305. http://dx.doi.org/10.1016/j.schres.2004.02.019

[89] R. Roncone, C. Tozzini, M. Mazza, A. de Risio, P. Giosuè, P. Morosini and M. Casacchia, "Validation of the Italian Version of the Self Report Insight Scale,” Epidemiologia e Psichiatria Sociale, Vol. 12, No. 1, 2003, pp. 63-75. http://dx.doi.org/10.1017/S1121189X00006060

[90] D. Travers, D. Levoyer and B. Millet, "Insight in Schizophrenia: Assessment of 31 Patients with Different Scales," L'Encéphale, Vol. 34, No. 1, 2008, pp. 66-72. http://dx.doi.org/10.1016/j.encep.2007.01.001

[91] M. Bell, J. Fiszdon, R. Richardson, P. Lysaker and G. Bryson, “Are Self-Reports Valid for Schizophrenia Patients with Poor Insight? Relationship of Unawareness of Illness to Psychological Self-Report Instruments,” Psychiatry Research, Vol. 151, No. 1, 2007, pp. 37-46. http://dx.doi.org/10.1016/j.psychres.2006.04.012

[92] E. Schaeffer and J. Wciórka, "Self-Rating Scales in Schizophrenia: Assessment of the Practical Applicability of the Paranoid-Depression Scale (PD-S), the Frankfurt SelfFeeling Scale (FBS) and of Two Visual Analogue Scales,” Psychiatria Polska, Vol. 37, No. 2, 2003, pp. 315-335.

[93] A. Osman, P. M. Gutierrez, J. L. Wong, S. Freedenthal and C. L. Bagge, "Development and Psychometric Evaluation of the Suicide Anger Expression Inventory,” Journal of Psychopathology and Behavioral Assessment, Vol. 32, No. 4, 2010, pp. 595-608. http://dx.doi.org/10.1007/s10862-010-9186-5 
[94] H. A. Wolters, R. Knegtering, D. Wiersma and R. J. van den Bosch, "Evaluation of the Subjects' Response to Antipsychotics Questionnaire," International Clinical Psychopharmacology, Vol. 21, No. 1, 2006, pp. 63-69. http://dx.doi.org/10.1097/01.yic.0000185023.55903.ba

[95] A. Awad, L. Voruganti, J. Mackell and C. Siu, "Subjective Tolerability with Ziprasidone Vs Haloperidol in Acute Schizophrenia," ISPOR 8th Annual International Meeting, Arlington, 18-21 May 2003.

[96] L. Fialko, P. A. Garety, E. Kuipers, G. Dunn, P. E. Bebbington, D. Fowler and D. Freeman, "A Large-Scale Validation Study of the Medication Adherence Rating Scale (MARS),” Schizophrenia Research, Vol. 100, No. 1, 2008, pp. 53-59. http://dx.doi.org/10.1016/j.schres.2007.10.029

[97] T. P. Hogan, A. G. Awad and R. Eastwood, "A Self-Report Scale Predictive of Drug Compliance in Schizophrenics: Reliability and Discriminative Validity,” Psychological Medicine, Vol. 13, No. 1, 1983, pp. 177-183. http://dx.doi.org/10.1017/S0033291700050182

[98] J. Chen, H. Ascher-Svanum, M. G. Case, A. Nyhuis, D. Faries, G. Phillips and D. O. Perkins, "Reasons for Continuing or Discontinuing Olanzapine in the Treatment of Schizophrenia from Patients' and Clinicians' Perspectives,” ISPOR 15th Annual International Meeting, Atlanta, 1519 May 2010.

[99] A. W. Nyhuis, H. Ascher-Svanum, V. Stauffer, B. J. Kinon, D. E. Faries, G. A. Phillips and D. Perkins, "Reasons for Discontinuation and Continuation of Antipsychotic Therapy from Patient and Clinician Perspectives," ISPOR 14th Annual International Meeting, Orlando, 16-20 May 2009.

[100] D. Rofail, R. Gray and K. Gournay, “The Development and Internal Consistency of the Satisfaction with Antipsychotic Medication Scale," Psychological Medicine, Vol. 35, No. 7, 2005, pp. 1063-1072. http://dx.doi.org/10.1017/S0033291705004526

[101] C. R. Dolder, J. P. Lacro, K. A. Warren, S. Golshan, D. O. Perkins and D. V. Jeste, "Brief Evaluation of Medication Influences and Beliefs: Development and Testing of a Brief Scale for Medication Adherence,” Journal of Clinical Psychopharmacology, Vol. 24, No. 4, 2004, pp. 404-409. http://dx.doi.org/10.1097/01.jcp.0000130554.63254.3a

[102] E. Lindström, T. Lewander, U. Malm, U. F. Malt, H. Lublin and U. G. Ahlfors, "Patient-Rated versus ClinicianRated Side Effects of Drug Treatment in Schizophrenia. Clinical Validation of a Self-Rating Version of the UKU Side Effect Rating Scale (UKU-SERS-Pat),” Nordic Journal of Psychiatry, Vol. 55, Suppl. 44, 2001, pp. 5-69.

[103] R. McGuire-Snieckus, R. McCabe, J. Catty, L. Hansson and S. Priebe, "A New Scale to Assess the Therapeutic Relationship in Community Mental Health Care: STAR,” Psychological Medicine, Vol. 37, No. 1, 2007, pp. 85-95. http://dx.doi.org/10.1017/S0033291706009299

[104] N. J. Preston and T. J. Harrison, "The Brief Symptom Inventory and the Positive and Negative Syndrome Scale: Discriminate Validity between a Self-Reported and Observational Measure of Psychopathology," Comprehensive Psychiatry, Vol. 44, No. , 2003, pp. 220-226. http://dx.doi.org/10.1016/S0010-440X(03)00010-5

[105] E. C. Atbaşoğlu, C. Kalaycioglu and E. Nalçaci, "Reliabi- lity and Validity of Turkish Version of Magical Ideation Scale in University Students,” Turk Psikiyatri Dergisi, Vol. 14, No. 1, 2003, pp. 31-41.

[106] G. M. Galeazzi, P. Spiliopulos and P. Curci, "Eppendorf Schizophrenia Inventory (ESI): Presentazione Della Versione Italiana,” Italian Journal of Psychopathology, Vol. 10, No. 3, 2004, pp. 322-330.

[107] R. Mass, C. Haasen and E. J. Borgart, “Abnormal Subjective Experiences of Schizophrenia: Evaluation of the Eppendorf Schizophrenia Inventory,” Psychiatry Research, Vol. 135, No. 2, 2004, pp. 91-101. http://dx.doi.org/10.1016/j.psychres.2004.08.011

[108] M. J. Cuesta, V. Peralta and I. Irigoyen, "Factor Analysis of the Frankfurt Complaint Questionnaire in a Spanish Sample,” Psychopathology, Vol. 29, No. 1, 1996, pp. 4653. http://dx.doi.org/10.1159/000284971

[109] T. W. Kallert and I. Nitsche, "Assessing the Opinions of Relatives on the Causes and Social Consequences of Different Mental Disorders: Are Instruments Cross-Culturally Valid?” Psychiatry Research, Vol. 158, No. 3, 2008, pp. 344-355. http://dx.doi.org/10.1016/j.psychres.2007.01.00 7

[110] F. Hjärthag, L. Helldin and T. Norlander, "Psychometric Properties of the Burden Inventory for Relatives of Persons with Psychotic Disturbances,” Psychological Reports, Vol. 103, No. 2, 2008, pp. 323-335.

[111] K. T. Kronmüller, C. Krummheuer, F. Topp, S. Zipfel, W. Herzog and M. Hartmann, "The Family Emotional Involvement and Criticism Scale,” Psychotherapie, Psychosomatik, Medizinische Psychologie, Vol. 51, No. 9-10, 2001, pp. 377-383. http://dx.doi.org/10.1055/s-2001-16897

[112] M. C. Park, Y. H. Ko, S. W. Oh and J. I. Park, "The Utility of the MMPI-2 and PAI for Discriminating the Patients with Schizophrenia and Depression in Korea," 23rd European College of Neuropsychopharmacology, ECNP Congress, Amsterdam, Conference Start: 28 August-1 September 2010.

[113] J. Van Os, A. C. Altamura, J. Bobes, J. Gerlach, J. S. Hellewell, S. Kasper, D. Naber and P. Robert, "Evaluation of the Two-Way Communication Checklist as a Clinical Intervention: Results of a Multinational, Randomised Controlled Trial,” The British Journal of Psychiatry, Vol. 184, 2004, pp. 79-83. http://dx.doi.org/10.1192/bjp.184.1.79

[114] A. M. Dassori, A. L. Miller and P. J. Weiden, "The Approaches to Schizophrenia Communication (ASC) Tool. Including the Patient Perspective in Treatment,” Disease Management \& Health Outcomes, Vol. 11, No. 11, 2003, pp. 699-708. http://dx.doi.org/10.2165/00115677-200311110-00002

[115] M. Corbière, A. Lesage, S. Lauzon, N. Ricard and D. Reinharz, "Validation Française du Questionnaire "Verona Service Satisfaction Scale’ VSS-54F,” L'Encéphale, Vol. 29, No. 2, 2003, pp. 110-118.

[116] D. Bletsa and E. Kallinikou, “Translation, Greek Adaptation and Standardization of the verona Service Satisfaction scale (VSSS-54): An Instrument Patients' Satisfaction with Mental Health Services," (PMH18) ISPOR 8th European Congress, Florence, 6-8 November 2005. 